\title{
Shoes, Canoes, and Lives in Unexpected Archives: Searching in Fur Trade Ledgers beyond the Hudson's Bay Company Archives
}

\author{
Stacy Nation-Knapper, Wilson Institute for Canadian History at McMaster University
}

\begin{abstract}
This article illuminates the existence and utility of fur trade ledgers and account books held in repositories beyond those held in the Hudson's Bay Company Archives. While the vast holdings of the HBCA are a phenomenal resource for researchers of the North American fur trade, many smaller repositories across the continent hold fur trade sources that can complement research conducted in other institutions. Such sources can, when examined with an eye to the cultural information they contain, reveal far more about the cultural history of North America than simply the economic data for which they were created.
\end{abstract}

In the process of establishing fur trading posts across North America, the North West Company and Hudson's Bay Company (HBC) also established ledger systems to track company expenditures and income at each post. ${ }^{1}$ Thousands of extant ledgers exist and, while many are housed in the Hudson's Bay Company Archives (HBCA) at the Archives of Manitoba, others are scattered in repositories across the continent. Thirty separate ledgers from the Temiskaming ${ }^{2}$ District of the HBC, containing "Indian Debts," rations, and transactions for the years between 1826-1890, are held by the Archives of Ontario (AO) and provide detailed information about this

\footnotetext{
${ }^{1}$ The terms "account book" and "ledger" are used interchangeably here, to avoid monotony in the text and because both are acceptable in this context, according to the Hudson's Bay Company Archives' "Types of Post Records" definitions. When specifically referencing the 'Indian Debts Ledger' and 'Voyagers \& Indian Provision Book, Grand Lac' I occasionally refer to them as "provision books" when referencing the provisions portions of the documents, because both record provisions. "Ledgers" and "account books" are differentiated from "post journals" primarily by their lack of narrative and their preponderance of numerical tallies. "Types of Post Records," Hudson's Bay Company Archives website, accessed April 29, 2013. http///www.gov.mb.ca/chc/archives/hbca/resource/post_rec/ types.html

${ }^{2}$ The spelling of Temiskaming has varied greatly over time. I have chosen the spelling used in the sources cited here and by the $\mathrm{AO}$ in their finding aid. For an exploration of the etymology of "Temiskaming," see Elaine Allan Mitchell, Fort Timiskaming and the Fur Trade (Toronto: University of Toronto Press, 1977), xv or Donat Martineau, OMI, Le Fort Timiskaming (Rouyn, Québec: La Société Sain-Jean-Baptiste de l'Ouest Québécois, 1977), 4. Similarly, the sources used here use the term "voyager" in reference to men outfitted for fur trade expeditions and I maintain that usage.
} 
well-documented fur trade district. ${ }^{3}$ The detailed accounting in these ledgers furnishes more than the budgetary information for which it was initially valued, providing students of aboriginal and fur trade history an entry point into the quotidian experiences of Indigenous life within HBC territories of influence and allowing for analysis of Indigenous influence upon the fur trade economy. These ledgers convey more than simply moments of commercial exchange; they reveal details about individual people, and their lives and experiences in the North American fur trade. While archives such as the HBCA and Library and Archives Canada (LAC) contain multitudes of valuable fur-trade-era sources, local, state, and provincial archives hold materials to enrich research done in larger archives. The Temiskaming District holdings of the AO, examined here, are but one example of the treasures of unexpected archives revealing the social and cultural history of the North American fur trade.

The Temiskaming District holdings at the AO consist of thirty-six files of textual information, of which thirty are ledger books, two are accounting documents, two are accounting books, one a collection of loose accounting pages, and one contains accounting correspondence for the district. While all thirty-six files are available with no restrictions through the reading room of the AO, some of the files are photocopies of the original documents. The Archives provides photocopying and mailing services at a charge.

All records discussed here document points of exchange and bookkeeping concerns of various fur trade posts within the district. The geographical area that came to be known as the

\footnotetext{
${ }^{3}$ The Temiskaming District holdings are in sub-series F471 of the AO, titled Fur Trade Collection under the records title Hudson's Bay Company records. Some of the documents held here may also be held in the HBCA, though it does not appear that the many ledgers in AO holdings are also in HBCA holdings. "Temiskaming Accounting Ledger, 'Indian Debts Ledger', 1832-1838" and "Temiskaming Account Book, 'Voyagers \& Indian Provision Book, Grand Lac', 1868-1869," Archives of Ontario. The finding aid in the AO states that the 'Indian Debts Ledger' dates from 1832, but the document used here is the 1837-1838 'Indian Debts ledger'. One item, F 471-2-0-29, holds materials dating from 1784-1821, predating the HBC/NWC merger.
} 
HBC Temiskaming District is located approximately halfway between what is now Toronto, Ontario and the southern tip of James Bay. In the twenty-first century, the area of Temiskaming is popular cottage country for people living in Ottawa and Montreal, but it has long been the home of multiple groups of Indigenous peoples. The Algonquian Timiskaming First Nation currently enumerates its members at 1,650, and although the Timiskaming Reserve was established in 1851, the Timiskaming people inhabited the area long before Europeans arrived. ${ }^{4}$ The current reserve is just east of the provincial border between Ontario and Québec, at the north end of Lake Timiskaming. Most of the Indigenous communities in the region currently identify as Algonquian, but prior to the establishment of reserves in Canada, Algonquian, Montagnais, Ojibwe, and Cree peoples lived in and traveled throughout this area. ${ }^{5}$ It is with the ancestors of these groups of people that the transactions noted in fur trade accounting ledgers occurred and whose actions are carefully recorded, revealing much about their daily lives. The HBC Temiskaming District contained at most five stores or posts, depending on the year, some of which retained their name while changing location; others opened and closed as the trade dictated. ${ }^{6}$ Two of the AO Temiskaming District holdings are examined in detail here. The 'Indian Debts Ledger' for 1837-38 appears to be for the district as a whole, while the 'Voyagers and Indian Provision Book' indicates it is from the Grand Lac post. Grand Lac was one of two posts, the other being Fort Temiskaming, that remained open consistently following the 1821 merger of

4 “Our Community," Timiskaming First Nation website, accessed April 25, 2013. http:// www.timiskamingfirstnation.ca/ourcommunity.html. The Timiskaming reserve is not the only reserve in the area. Others include those of Beaverhouse, Temagami, and Winneway First Nations. The Temagami reserve is on Bear Island, where the final HBC store in the district was located until 1970.

${ }^{5}$ Mitchell, Fort Timiskaming and the Fur Trade, 14-15.

6 Gwen Reimer and J-P Chartrand, "Review of Reports and Cartographic Representation Pertaining to Historic Métis in Ontario," Peterborough, ON: Praxis Research Associates for Native Affairs Unit, Ontario Ministry of Natural Resources, 2002), 48. 
the HBC and the North West Company (NWC). ${ }^{7}$ The thirty ledgers in the collections of the AO cover several posts in the district over the nineteenth century, providing a broad survey of fur trade activity in the region.

The Temiskaming ledgers in the AO are all formatted in order to track people or goods; therefore, they are composed largely of lists and tables. Depending on the purpose of the document, it may be organized as a list of goods or a list of individuals, with tallies attached to each entry. In the case of the provision book, it is comprised of multiple types of lists including people and rations they received, goods and services received or delivered, transfers between posts, trades for fresh food, and lists of "Indians" supplied with rations. The Indian Debts Ledger is similar in form and has some overlap with the provision book, but instead of an ongoing and changing list of names, this ledger provides an entry per "Indian" individual and tallies the individual's trading activity over the course of the year. Each of the Temiskaming ledgers held in the $\mathrm{AO}$ varies somewhat from the next, but the overall intention of these records is the same - to track goods and services in order to monitor HBC expenses and income.

Fur trade ledgers from the Temiskaming District housed in the AO are an accessible, plentiful, mostly legible source of information regarding Indigenous people and HBC activity in the region. In spite of this, these sources remain largely unused in the fur trade historiography while offering much insight into the human, and possibly even animal, activities in the region.

The fur trade in Temiskaming began in the early seventeenth century, with the first post established in the early 1670 s. The last HBC store in the region closed September $10,1970 .{ }^{8}$ In

\footnotetext{
${ }^{7}$ Mitchell, Fort Timiskaming and the Fur Trade, ix.

8 Ibid., ix, 4; “Temagami online post history,” Hudson's Bay Company Archives website, accessed April 17, 2013. http://pam.minisisinc.com/scripts/mwimain.dll/12091/AUTHORITY_LINK/NAME/Temagami?JUMP
} 
the three intervening centuries the North West Company maintained posts in the region, individual traders from nearby European settlements engaged actively in trading furs with the Indigenous peoples of the Temiskaming region, and the NWC merged with the HBC. In part due to its location, but also because it was "one of the most profitable of all the Company's" areas of influence in the nineteenth century, the HBC Temiskaming District is well documented. ${ }^{9}$ Since the district was located near cities and hubs of commerce, the posts' ledgers and journals had shorter distances to travel than those of HBC posts in the farther reaches of the continent, thus surviving in far greater numbers. Surprisingly little has been written about the fur trade history of this region, considering the abundance of source material with which to work. Thus far, Elaine Allan Mitchell's Fort Timiskaming and the Fur Trade is the dominant historical work on the region, but as with many fur trade histories prior to 1980, Mitchell's book focuses mainly on the activities of elites in the fur trade. In the case of Fort Timiskaming and the Fur Trade, Mitchell focused on the plentiful writings of Chief Factor Angus Cameron and his family, who made the Temiskaming District something of a family enterprise for several generations. ${ }^{10}$ For this reason, Mitchell's focus is not on the daily experiences of the many people engaged in the trade, but on those select few directing the trade and their correspondence with the London office and each other. The activities of labourers in the fur trade at Temiskaming from the time the HBC acquired the post in the merger of 1821 until the last store closed in 1970 reveal a great deal about Indigenous influence on the business, as well as the ways in which the business itself changed in

\footnotetext{
${ }^{9}$ Mitchell, Fort Timiskaming and the Fur Trade, xi.

${ }^{10}$ Ibid., xi-xii. Although Mitchell utilized sources from the AO, neither the "Temiskaming Accounting Ledger, 'Indian Debts Ledger', 1832-1838" nor the "Temiskaming Account Book, 'Voyagers \& Indian Provision Book, Grand Lac', 1868-1869" is cited in Fort Timiskaming and the Fur Trade.
} 
the span of one hundred and fifty years. From outfitting fur trade canoe brigades and buying furs from local Indigenous people in the early nineteenth century, the posts began buying increasing quantities of Indigenous-made shoes and canoes by 1867, and as the twentieth century began, business shifted again to outfitting cottage-country tourists. The two ledgers examined here document some of these changes in the thirty years between 1837 and 1868, and the collection of ledgers at the $\mathrm{AO}$ provide more sources from which to identify patterns of trade and change over time.

While historians of the fur trade generally prefer post journals for their narrative details, accounting ledgers have also long been used as source material for historical writing. Harold Innis famously constructed an economic history of Canada from various sources, including fur trade ledgers, some of which he reproduced in his book's appendices; Arthur S. Morton wrote a history of western Canada utilizing some ledger sources in his work; and Arthur J. Ray used post account books extensively in reconstructing Indigenous people's consumption patterns and movements throughout North America in relation to the fur trade. ${ }^{11}$ These men were not, however, focusing on the ways in which the details held in fur trade account books reveal cultural knowledge about the daily lives of the people whose economic actions they record. Many other fur trade historians have looked to ledgers and account books to supplement cultural arguments, but these sources rarely provide the preponderance of evidence for their cultural

\footnotetext{
${ }^{11}$ Harold A. Innis, The Fur Trade in Canada: An Introduction to Canadian Economic History (New Haven: Yale University Press, 1930); Arthur S. Morton, A History of the Canadian West to 1870-71: Being a History of Rupert's Land (The Hudson's Bay Company's Territory) and of the North-West Territory (including the Pacific Slope) (Toronto: University of Toronto Press, 1939); Arthur J. Ray, Indians in the Fur Trade: Their Role as Trappers, Hunters, and Middlemen in the Lands Southwest of Hudson Bay, 1660-1870 (Toronto: University of Toronto Press, 1974).
} 
arguments. ${ }^{12}$ Similarly, reports commissioned for governmental entities, such as the "Review of Reports and Cartographic Representation Pertaining to Historic Métis in Ontario," utilize post journals, Indian Affairs correspondence, and census and school records in their supporting research, but seemingly overlook the value of the many extant account books for the Temiskaming District in their search for "direct evidence of a métis population" in the region. ${ }^{13}$ Though this report states that there are "no post journals" for Mattawa and that "fur trade records are scant" for the district in general, the HBC Archives hold Mattawa post account books for years falling within their study range, including 1868, 1869, 1888, 1889-96, 1904, and 1906 and the Temiskaming District ledgers held at the AO cover the study period, as well. ${ }^{14}$ The research methodologies used by these authors to tease cultural details from post journals are transferable to ledgers and account books, such as those of the Temiskaming District at the AO, to further understand the cultural experiences of people engaged in the fur trade.

The ways in which fur trade ledgers for the Temiskaming District have been used in historical research also tell us something about the ways in which future scholars could use them. The simple existence of these documents reveals some particulars of Indigenous life and experiences. The debts ledger for 1837-38 first and foremost indicates that Indigenous people were in debt to the $\mathrm{HBC}$ and provides a foundation from which it can be demonstrated that the

\footnotetext{
${ }^{12}$ Daniel Francis and Toby Morantz, Partners in Furs: A History of the Fur Trade in Eastern James Bay, 1600-1870 (McGill-Queen's University Press, 1983); John C. Jackson, Children of the Fur Trade: Forgotten Métis of the Pacific Northwest (Missoula: Mountain Press Publishing Company, 1995); Theodore J. Karamanski, Fur Trade and Exploration: Opening the Far Northwest, 1821-1852 (Norman: University of Oklahoma Press, 1983); Elizabeth Vibert, Traders' Tales: Narratives of Cultural Encounters in the Columbia Plateau 1807-1846 (Norman: University of Oklahoma Press, 1997).

${ }^{13}$ Reimer and Chartrand, "Review of Reports and Cartographic Representation Pertaining to Historic Métis in Ontario," 48.

${ }^{14}$ Ibid.; "Post Records Finding Aid, Mattawa," Hudson's Bay Company Archives website, accessed April 29, 2013. http://www.gov.mb.ca/chc/archives/hbca/resource/post_rec/post22.html\#312.
} 
definition of Indigenous debt and the $\mathrm{HBC}$ accounting structure in the Temiskaming District changed in the years between 1837 and 1868. In the course of thirty years, a shift in accounting occurred from recording individual commercial exchanges to recording running tallies of rations expended or trades received as a post. Details of individuals' purchases beyond the staple categories of flour, corn, grease, pork, salt, and butter are not recorded in the later accounts, but far greater detail is provided about individuals' labour for the post and how they were compensated for their work. ${ }^{15}$ The changes that took place in the Temiskaming District's accounting methods indicate that, as interdependence between the company and Indigenous individuals increased, the method for keeping accounts became increasingly communal in nature. This could be due to the increased complexity of post accounting as populations surrounding the post rose, or to $\mathrm{HBC}$ adapting accounting methods to its shifting dependence upon Indigenous items. It is also possible that yet another account book existed for 1868 in which was kept details of the sales of sundry goods. In either case, the changes in HBC bureaucratic methods indicate that Indigenous activity may have required the company to adapt its record-keeping to Indigenous people's activity at the posts. Surveying ledgers held in local, state, or provincial archives, such as the AO Temiskaming District ledgers, would test this hypothesis.

Ledgers provide the names of Indigenous people engaged in trade in the Temiskaming District. For example, the debt ledger begins with an alphabetical index of aboriginal peoples carrying debts there by name and age, with some listed as relatives of others. ${ }^{16}$ Much information can be gleaned from the two pages of this index, including the names of people at the post in a

\footnotetext{
15 “Temiskaming Account Book, 'Voyagers \& Indian Provision Book, Grand Lac', 1868-1869.”

16 “Temiskaming Accounting Ledger, 'Indian Debts Ledger', 1832-1838,” 2-3.
} 
given year and any family that may have accompanied them, since even children as young as two years old were listed. Some individuals' names are crossed off the index and others are crossed off with the term "estate" written next to their name. It is unclear if this notation indicates death, migration away from post, or the full repayment of debts, but it is clear that the HBC bookkeeper was following the movement of all Indigenous people involved in trade at the post. Also noted next to some names are their status within families, such as "mother," "son," "widow," "wife," and one instance of "daughter." 17 Though the later provision book has no index, individuals' names are listed as rations were supplied and trades made, providing a similar account of who was in the district in 1868-69. ${ }^{18}$ Not only is it possible for historians to note the identities of Indigenous individuals present and economically engaged with the HBC during these two periods, but the two documents can be compared to determine who among these people and their families remained in the district or returned years later. In these ways, the account books act as censuses, identifying and enumerating individuals in the Temiskaming District. This information is potentially quite valuable to communities seeking to follow individuals, families, and communities through time in this place. Not only are people's names and relations noted, but so too are their activities at the post, providing details about community knowledge and skills in the mid-nineteenth century.

Beyond identification and migratory activity, these records are also evidence of the transfer of goods between the HBC and Indigenous people in the process of exchange. When compared to one another, the ledgers make apparent Indigenous peoples' increased trading with

\footnotetext{
${ }^{17}$ Ibid.

18 “Temiskaming Account Book, 'Voyagers \& Indian Provision Book, Grand Lac', 1868-1869.”
} 
the $\mathrm{HBC}$ for foodstuffs as well as the increased reliance of the $\mathrm{HBC}$ on Indigenous partners for necessities such as shoes, canoes, and meat. They also describe those material goods being used by aboriginal people and how items changed both seasonally and over a period of time. The four most common items rationed to Indigenous people at the Temiskaming District were flour, corn, grease, and pork. ${ }^{19}$ In the $1837-38$ ration accounts, rum, wheat, and salt are also listed as occasional ration items, while butter and barley are the rations novelties in the 1868-69 ledger. ${ }^{20}$ The availability and patterns of use of certain rations selections changed over time. In 1837-38, little flour was used and most Indigenous people acquiring rations were receiving corn, while in 1868-69 most of the rations received were in the form of flour. Seasonal fluctuations also occurred. Historians can glean from this information that Indigenous people were possibly acquiring food through other means during these times, and perhaps follow climactic variations to understand why certain rations were favored over others in particular years. For example, flour and grease were more heavily used between June and September of 1868, while by October more pork was being distributed than other items. ${ }^{21}$ These changes could be attributed to Indigenous hunting during the summer months, thus less reliance upon the post for meat or the possibility of trade with other Indigenous groups for meat in the summer or corn in the fall. It is also possible that some rations were simply unavailable to the post a given time. ${ }^{22}$ These ledgers provide an

\footnotetext{
19 “Temiskaming Accounting Ledger, 'Indian Debts Ledger', 1832-1838,” 86-120; “Temiskaming Account Book, 'Voyagers \& Indian Provision Book, Grand Lac', 1868-1869,”' 1-29.

20 “Temiskaming Accounting Ledger, 'Indian Debts Ledger', 1832-1838," 86-90, 120; “Temiskaming Account Book, 'Voyagers \& Indian Provision Book, Grand Lac', 1868-1869,’ 3-8, 20-29.

21 “Temiskaming Account Book, 'Voyagers \& Indian Provision Book, Grand Lac', 1868-1869,” 1-21.

22 The ledgers only provide an annual inventory of post holdings though an examination of communications between posts could possibly determine the availability of rations at the post.
} 
indicator that not all Indigenous necessities were acquired through the $\mathrm{HBC}$, raising further questions concerning trade beyond the post and seasonal migration and consumption patterns.

Regional comparisons can be made using fur trade ledgers such as those at AO. For example, Elaine Mitchell notes the "ubiquitous corn soup" consumed at fur trade posts in the Temiskaming District, pointing out that "there was no pemmican in the Timiskaming district, (so) winterers and engagés alike had had to depend on corn and grease for voyaging." 23 This regional variation and Mitchell's inclusion of cooking instructions helps explain why certain rations were provided to both voyagers and Indigenous people over other foodstuffs in districts farther west. Since these rations were sent with voyagers as they embarked on journeys from the Temiskaming District for other fur trade regions, they brought the regional delicacies with them to other posts along their routes. It is possible that voyagers and other HBC employees had regional rations preferences, and account books are a rich source from which to begin such an investigation into quotidian culinary fur trade experiences. Food was a considerable distraction for workers in the fur trade, and much time and energy was spent thinking about, pursuing, and consuming food. ${ }^{24}$ Historians or anthropologists concerned with the nutritional content of aboriginal diets and those of voyagers at the time could also use ledgers such as those in the AO to begin an inquiry into the caloric and qualitative nature of food consumption near HBC posts.

In addition to foodstuffs, aboriginal peoples in the Temiskamingue District bought tools such as axes, hooks, kettles, and twine. By examining the frequency of trade in these tools, an increase in their use is discernible, and it becomes possible to learn something about their

\footnotetext{
${ }^{23}$ Mitchell, Fort Timiskaming and the Fur Trade, 7.

${ }^{24}$ Carolyn Podruchny, Making the Voyageur World: Travelers and Traders in the North American Fur Trade (Lincoln: University of Nebraska Press, 2006), 8, 68-69, 119, 177, 205.
} 
construction quality. In early April of 1838, a person named Petrimeause Minivanikyick purchased multiple knives, but was back in August for several more. It is possible that the first knives were traded to others or perhaps lost, but given the ledger activity for this individual in the interlude, it is reasonable to think the knives were worn down in the course of daily activities. In April and May, Petrimeause Minivanikyick brought twenty-five furs to the post, on June 7 this person purchased twine and hooks and brought in sixteen more pelts, and in July they bought hooks, twine, and fish spears. ${ }^{25}$ Clearly, this individual was engaged in activities that would put knives to rigorous use, and it is likely that they were using these items, rather than passing them along in the chain of exchange. Somewhat surprisingly, the HBC accepted returns on defective tools in the Temiskaming District. On May 18, 1837, Endainois returned "1 Crooked knife" in exchange for another, presumably straight, implement. ${ }^{26}$ This small entry demonstrates the possibility that some HBC trade goods were not high-quality items, but also that in some instances Company employees were willing to exchange inferior goods for their customers. This incident also sheds light on Indigenous consumer behaviors in the early nineteenth-century Temiskaming region. Endainois, for one, was comfortable enough doing business at the post (presumably) to be willing to demand a new knife for the crooked one received previously. A study of exchange and return behaviors among HBC posts represented in the AO's collection of ledgers could potentially reveal much about consumer and supplier behavior, as well as the ways in which these behaviors may have influenced supply decisions within the Hudson's Bay Company, if at all.

\footnotetext{
25 “Temiskaming Accounting Ledger, 'Indian Debts Ledger’, 1832-1838,” 44.

${ }^{26}$ Ibid., 26.
} 
Indigenous people expanded their existing wardrobes with the purchase of European items, including capots, leather belts, pants, and shirts from $\mathrm{HBC}$ posts. ${ }^{27}$ For example, an individual identified as Canataowitch purchased a capot, a hooded coat made from a wool blanket, on September 13, 1837 and another on May 30 of the following year. Based on the large number of furs this person traded to the post in the interim, it is probable that the capot purchased in the fall was fairly worn out by spring, requiring replacement. ${ }^{28}$ If this person bought a new coat in the fall and completed difficult physical labour throughout the winter (evidenced by the number of furs brought to the post), they would probably have worn through the first coat, requiring the purchase of another in the spring. In addition to clothing, non-essential items such as soap, combs, ribbon, and silk thread were also purchased, indicating exchange beyond items of immediate necessity. ${ }^{29}$ These items also reveal cultural changes within aboriginal communities around HBC posts. The use of European-made soap to clean bodies as well as belongings is a European cultural trait introduced to North America. Fur trade ledgers documenting soap consumption provide scholars with evidence of daily cleansing activities in the fur trade and the ways those activities changed over time. Additionally, these ledgers provide potential resources for environmental historians tracking soap consumption in North America to follow water quality changes or to track commodities flows. ${ }^{30}$

\footnotetext{
${ }^{27}$ Ibid., 5, 7, 9.

${ }^{28}$ Ibid., 4.

${ }^{29}$ Ibid., 5, 6.

${ }^{30}$ As one of many examples, the Trading Consequences project is one potential tool that could be coupled with fur trade ledgers to track soap as a commodity in the nineteenth century. "Trading Consequences: A Digging into Data Project," accessed April 29, 2013. http://www.jimclifford.ca/2012/02/10/trading-consequences-a-digging-into-dataproject/.
} 
Items such as combs, ribbon, and silk listed as trade goods in the Temiskaming account books indicate that Indigenous people were integrating these components into their material creations. For museums or historians of material culture, these ledger entries provide documentary evidence that Indigenous peoples were using these materials in the early nineteenth century, potentially supporting collections descriptions or aiding in the identification of communities of origin. For community members trying to understand how and when European trade goods became used in the creation of material objects, the documentation of their trade provides a material line of descent from which to understand the course of cultural change. Since many of these items are linked in the 1837 ledger directly to named individuals, families such as that of Hitachkiminan, who purchased ribbon and silk thread, may even be able to trace the material culture of their family's beadwork or ribbonwork through these documents. ${ }^{31}$ The tracking of $\mathrm{HBC}$ rations and sales to Indigenous people in the Temiskaming District provides historians with evidence of Indigenous consumption patterns, moments of individual agency in the early stages of North American capitalism, evidence of changing material culture, and evidence of commodities flows in global markets.

The AO ledgers for the Temiskaming District indicate that Indigenous people provided the Temiskaming post with not only furs but also other goods, demonstrating a complex and symbiotic fur trade economy. In the 1837-38 ledger, sizable quantities and varieties of furs are tallied against individuals' debts, including beaver, martin, otter, "cat," rat, fisher, bear, and

\footnotetext{
31 “Temiskaming Accounting Ledger, 'Indian Debts Ledger', 1832-1838," 5.
} 
mink. ${ }^{32}$ One example of trade is the largest credit to the account of "Louison (Lafrance's son)"33 from June 5 of 1837 , for " 3 otters, 1 mink \& 2 rats," but also " 1 Moose skin." With the credit for these valuable furs, Louison purchased a "Frock Coat...Strouds" and an "axe for (his) mother."34 In addition to pelts, Indigenous peoples sold tanned hides, canoes, moose meat, and their labour to the post. ${ }^{35}$ In October of 1837 , Wabikiyeck was paid for service in a voyage to French River. ${ }^{36}$ In July of the same year, Nawaygush, his wife, and Mishel were all paid in rations for bringing food to the fort, Nawaygush brought "meet" and Mishel brought " 2 cat fishes." ${ }^{37}$ In the context of the North American fur trade, it is not surprising that fur is the commodity most commonly exchanged, but it was not the only product sought by the HBC. Ledgers such as these detail the varied products exchanged.

The HBC market for Indigenous goods and labour at Temiskaming grew considerably over time. In the smaller, later ledger of 1868, increased diversity in Indigenous-made wares sold and traded to the Company is evident. Indigenous peoples frequently engaged in making shoes, as is noted on nearly every page of the account book, and the activities of making and gumming canoes and tanning hides appear regularly. ${ }^{38}$ In June of 1868 alone, "Post Labour \& Expenses" were recorded for various aspects of canoe-related labour from making to gumming the craft, ${ }^{32}$ Ibid., 4, 64.

${ }^{33}$ Notations such as this are also compelling, in the context of the document. Louison, "Lafrance's son", is included in the "Indian Debts Ledger" and was, apparently, considered "Indian" by the keeper of the ledger. In the context of the fur trade, it is possible that this was a métis man, and this information could contribute to reports such as the "Review of Reports and Cartographic Representation Pertaining to Historic Métis in Ontario" cited above.

${ }^{34}$ Ibid., 32.

${ }^{35}$ Ibid., 16, 25, 27, 31 .

${ }^{36}$ Ibid., 62.

${ }^{37}$ Ibid., 90 .

38 “Temiskaming Account Book, 'Voyagers \& Indian Provision Book, Grand Lac', 1868-1869,” 2. 
with multiple entries noting "women at canoes." ${ }^{39}$ In the same month, five days contain labour expense entries for "making shoes." ${ }^{40}$ Indeed, the first seven pages of the "Voyagers \& Indian Provision Book" detail labour expenses at the Grand Lac post, illustrating the importance of both Indigenous labour and expertise to the Hudson's Bay Company. Beyond the Company paying for Indigenous labour, it was also paying them directly for finished products. In June of 1868, the same month the HBC paid multiple Indigenous people to make shoes, it also purchased finished shoes in ten individual transactions. ${ }^{41}$ In July of the same year, the HBC purchased shoes ten additional times from Indigenous individuals. ${ }^{42}$ The prices given indicate that these items were of value to the $\mathrm{HBC}$ and that a need existed for them. These transactions also present compelling research questions about the trade in the Temiskaming District regarding the quality and creation of shoes in this region, the skills of their creators, and the overall supply chain of shoes in the Hudson's Bay Company, all questions that can be partially answered with the use of HBC account books and ledgers in the AO. These documents also indicate that the Indigenous people of the Temiskaming District spent some of their time engaged in hunting, tanning, building, and labouring beyond the harvest of furs to participate in the fur trade economy.

HBC ledgers furnish evidence that there were gendered divisions of daily labour and activity at the posts. It is apparent from the names and descriptions provided in ledgers, such as those at the AO, that women most frequently received rations. As scholar Sherry Farrell Racette

\footnotetext{
${ }^{39}$ Ibid., 4.

${ }^{40}$ Ibid.

${ }^{41}$ Ibid., 10-12.

${ }^{42}$ Ibid., 12-16.
} 
asks, "[w]hy were so many trade goods directed at female consumers and creators?" 43 Women may have been responsible for acquiring rations, since they may have also been responsible for creating meals from the supplies. Racette states that "[w]ith few exceptions, the historical record is silent on the economic lives of women, making it difficult to track their activities as consumers and manufacturers." ${ }^{44}$ Fur trade ledgers such as those examined here are one of those exceptions. In the entries documenting exchanges with women, they were frequently listed as part of a malecentered family, such as "Jean Baptist's mother," "voyager's wife" or "blind man's wife," suggesting that $\mathrm{HBC}$ traders associated most women with male family members. ${ }^{45}$ Furthermore, women who were widowed or men who were widowers were noted as such, marking them as anomalous from the rest of the population and privileging European concepts of marriage and monogamy over those of Indigenous communities in the area. ${ }^{46}$ The HBC purchased goods and received goods in trade from both men and women, possibly creating gendered categories of trade. Women primarily sold shoes and furs in 1837-38 and expanded their sales in 1868-69 to also include canoes, salt beef, and fish. ${ }^{47}$ In the 1868-69 account books, however, shoes are overwhelmingly purchased from individuals identified as women. In 1837-38, men sold meat and furs but increasingly marketed their labour by 1868. Men were hired by the HBC to work around the post greasing axes, gardening, chopping wood, fishing, tending fire, cutting hay, and

\footnotetext{
${ }^{43}$ Sherry Farrell Racette, "My Grandmothers Loved to Trade: The Indigenization of European Trade Goods in Historic and Contemporary Canada," Journal of Museum Ethnography 20 (2008), 70.

${ }^{44} \mathrm{Ibid}$.

${ }^{45}$ Ibid., $1,16$.

46 “Temiskaming Accounting Ledger, 'Indian Debts Ledger', 1832-1838,” 2-3.

${ }^{47}$ Ibid., 8, 33, 34; “Temiskaming Account Book, 'Voyagers \& Indian Provision Book, Grand Lac', 1868-1869," $2-24$.
} 
hunting birds, while boys cleaned potatoes and tended cattle. ${ }^{48}$ In several tallies of canoe provisioning before brigade departures or on brigade arrivals, the gender of canoe occupants is noted. There are also notations of "women on departure" receiving rations prior to leaving the post. ${ }^{49}$ Gendered movement on the landscape can be tracked, to a degree, through AO HBC ledgers.

Children are present within these documents as well, reminding historians that the North American fur trade was a community environment extending beyond the moment of exchange. Children are noted by age in the 1837-38 index and are listed as "daughter," "boy," or "son" throughout the 1868-69 ledger. There are times when children are noted for receiving rations, potentially leading historians to examine the circumstances of these transactions. ${ }^{50}$ Adults may have sent them on errands, but they may also have been providing for siblings or elders, possibilities that can be fleshed out by following individuals through a series of ledgers or in conjunction with post journals, oral histories, or missionaries' writings. Boys provided labour to the post, and some are listed with their mothers' names and notes indicating the latter as widows. ${ }^{51}$ Within the ledgers are also notations of female children, identified as "daughters" who often accompanied their mothers to the post for rations. Occasionally daughters are noted as the primary receiver of rations for a family. These notations provide historians with the opportunity

\footnotetext{
48 “Temiskaming Account Book, 'Voyagers \& Indian Provision Book, Grand Lac', 1868-1869,” 2-5.

${ }^{49}$ Ibid., 10.

50 “Temiskaming Accounting Ledger, 'Indian Debts Ledger', 1832-1838," 11, 17, 25, 31, 32, 33, 39; “Temiskaming Account Book, 'Voyagers \& Indian Provision Book, Grand Lac', 1868-1869," 1-3, 10-16.

51 “Temiskaming Accounting Ledger, 'Indian Debts Ledger', 1832-1838,” 2-3.
} 
to study gender construction and interpretation among $\mathrm{HBC}$ employees within Indigenous communities, building on some of the seminal twentieth-century fur trade histories. ${ }^{52}$

As historian Jennifer S.H. Brown reminds us, while creative analysis of sources such as the Temiskaming District accounting ledgers at the AO can be used to produce "voluminous researches and innovative approaches that have greatly changed and amplified our views of these subjects," she cautions us that "there is still room for questions and even discomfiture at the state of our knowledge and the level of our understanding." ${ }^{, 53}$ As with any source, there are substantial omissions in the AO Temiskaming District accounting ledgers, resulting in much we cannot see. These documents are one small window onto complex, interconnected communities, and we must be aware of their, and our own, limitations. To utilize these records in the ways suggested here requires a strong understanding of not only fur trade networks of travel, trade, and communication, but also of Indigenous communities and their networking practices. Historians using sources such as these to investigate Indigenous communities should not make assumptions based on non-Indigenous cultural knowledge regarding families and networks of support. Temiskaming accounting ledgers were created by European men through the social and cultural frameworks that were their lived experiences. This is a problem inherent in the documents that must be addressed when putting them to work in historical analysis.

The Indian Debt Ledger of 1837-1838 and Provision Book of 1868-1869 for the Temiskaming District of the Hudson's Bay Company are two small ledgers of thirty held at the

\footnotetext{
52 Jennifer S.H. Brown, Strangers in Blood: Fur Trade Families in Indian Country (Vancouver: UBC Press, 1980); Podruchny, Making the Voyageur World: Travelers and Traders in the North American Fur Trade; Sylvia Van Kirk, Many Tender Ties: Women in Fur-Trade Society, 1670-1870 (Norman: University of Oklahoma Press, 1980).

53 Jennifer S. H. Brown, "The Blind Men and the Elephant: Fur Trade History Revisited," in Proceedings of the Fort Chipewyan and Fort Vermillion Bicentennial Conference, eds. Patricia A. McCormack and R. Geoffrey Ironside, (Edmonton: Boreal Institute for Northern Studies, University of Alberta, 1990), 16.
} 
$\mathrm{AO}$, and two of many thousands that have been preserved in archives throughout Canada. Though European and Euro-Canadian men created these ledgers for an overwhelmingly white, literate, male audience, they provide considerable information about the activities and experiences of Indigenous peoples living among HBC posts. From the lists of rations received and trades made can be extracted elements of Indigenous daily life and labour to construct a more nuanced depiction of aboriginal life in the fur trade. It becomes evident that the activities of Indigenous people altered the lives of non-Indigenous HBC employees and the ways in which they conducted business. Employees in the Temiskaming District reacted to Indigenous action within the fur trade economy to adjust accounting methods and market approach in order to maximize upon new commodities presented by Indigenous people. Through ledgers such as these, located in unexpected state, provincial, and local archives, the social and cultural history of the fur trade can be teased out to complement the vast fur trade historiography built on traders' narratives. 